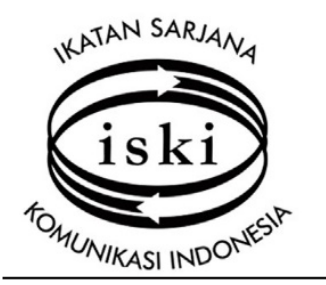

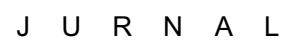

\title{
Social Network Strategy to Counter Acts of Terrorism in Indonesia: A Structural Hole Study
}

\author{
http://dx.doi.org/10.25008/jkiski.v6i2.603
}

\author{
Agus Surya Bakti, ${ }^{1 *}$ Hafied Cangara, ${ }^{2}$ Dwia Aries Tina Palubuhu, ${ }^{3}$ \\ Eriyanto $^{4}$ \\ ${ }^{123}$ Faculty of Social and Political Science, Universitas Hasanuddin \\ Jl. Perintis Kemerdekaan Km. 10 Tamalanrea, Makassar 90245 - Indonesia \\ ${ }^{4}$ Department of Communication Sciences, Universitas Indonesia \\ Jl. Salemba Raya No.4 Jakarta 10430 - Indonesia \\ *Corresponding author: agus84sb@gmail.com
}

Submitted: August 12, 2021, Revised: September 15, 2021, Accepted: November 30, 2021

Accredited by Kemristekdikti No. 28/E/KPT/2019

\begin{abstract}
The ISIS terrorist group still poses a serious threat in Indonesia, especially because it operates in a network (net-terrorism) so that the handling of this terrorist group often does not reach its roots. The research is aimed to reveal the social network strategy in resolving terrorist acts in Indonesia using a structural hole theory. The research method is a qualitative research approach with secondary data analysis from four sources: books, journal articles, previous related research, and the Law of the Republic of Indonesia. The data above is then processed with Ucinet-Draw to calculate the linkage score between members in the network and then see the movement map for each ISIS network in Indonesia: Jakarta, Poso, and Surabaya. Thus, this study proves that there is a gap in the structure of the ISIS group's communication network in Indonesia. The research results revealed that many terrorist acts in Indonesia had the same pattern, namely the strong communication network between terrorist actors. Terrorist actors carried out at least three tertius strategies, namely tertius gaudens, tertius inguens, and a combination of the two. Through the tertius strategy, the government will be able to play its most crucial role in taking preventive actions against actors in terrorist networks. Therefore, the government needed to carry out various integration strategies with various institutions to conduct deradicalization appropriately.
\end{abstract}

Keywords: ISIS threats; social network strategy; tertius strategy; prevention of terrorism; deradicalization of terrorism.

\section{Introduction}

In the history of the founding of the Unitary State of the Republic of Indonesia (NKRI), Indonesia has always experienced the dynamics of terror threat. Several studies say that the terror threat has increased in Indonesia since the early 2000 s so that the world's citizens focus their attention on this country (Bakti, 2014). Terrorism comes under the world's spotlight because terror acts have been agreed as extraordinary crimes that prompt countries worldwide to wage war on terrorism. As terrorism is defined as an act that uses violence or threatens with violence against the community or national security with any motive, it can create feelings of threat and fear in general (Bakti, 2016).

If traced from terror attacks from 2000 to 2011, there were at least ten cases of terrorism that killed 276 people and injured 748 others. These cases ranged from the terror attack at the Philippine Embassy in Jakarta in 2000 to the terror attack at the Cirebon Police Office mosque in 2011 (Hikam, 2016). Not only that, 
scary events have occurred in the last five years, including four cases in 2015, two cases in 2016, four cases in 2017, five cases in 2018, five cases in 2019, and four cases in 2020 (Farisa, 2021). Therefore, the number of terrorism cases in Indonesia in the last 10 years needs serious attention from the public, especially the government. Counterterrorism needs to be continuously improved for the sake of security and convenience to maintain national stability.

The various acts of terror that occurred in Indonesia above mainly involved individuals who had a radical understanding of religion. Despite the fact that terrorism does not always lead to religious issues, but rather to many more complex ones. Radicalism that leads to terrorist acts is also caused by dissatisfaction with something, feeling threatened by Western powers and vice versa, feeling marginalized by the majority group, and the despair of great hope. For these various reasons, acts of terrorism always use religious narratives to carry out these various actions.

There is a need for an extraordinary approach to reduce the number of terrorism cases in Indonesia, especially against the ISIS (Islamic State of Iraq and Syria) terrorism movement. At least two approaches need to be taken, namely hard approach and soft approach. Through the hard approach, the state uses surveillance, intelligence, arrest, and detention methods. Meanwhile, through the soft approach, the state makes various counternarrative and counter-ideological efforts, including understanding their networks and backgrounds (Aljunied, 2011).

The terror group that currently poses a threat to various countries in the world is ISIS. Research shows that ISIS continues to carry out its acts of terror due to solid technology among its members. Even in Indonesia itself, the teachings and movements of ISIS are mainly through the internet (Fitriani, Putri, Sari, \& Adriana, 2018). Through Al-Mustaqbal's online media, the FAKSI (Indonesian Sharia Activist Forum) group openly opens up information about the ISIS movement. Not only does FAKSI spread the content of ISIS movements and da'wah, but also it sends its members to ISIS headquarters, such as Bahrun Syah and Salim Mubarok (IPAC, 2014). Finally, these two members mobilized their network by creating an Indonesia-Malaysia terror group in Syria in the hope of establishing a caliphate state.

Through online media, terrorist actors build communication with their networks. The elite of their group actors can construct a free discussion space so that online media for terrorism groups is very effective in conveying messages to their network. Through it, terrorist actors also have the opportunity to build a consolidation forum to carry out political movements, make important decisions, and build narratives of jihad da'wah in public spaces. Online media can change from individual action to collective action and from persuasive to confrontational (Karlsen, 2015).

The rapid movement of ISIS in Indonesia is fully supported by FAKSI and by two other groups, namely Tauhid wal Jihad and Jamaah Ansharut Tauhid. From these three groups, the ISIS terror movement spread widely throughout Indonesia because, from the start, ISIS tried to convince Muslims that ISIS offered a new concept and ideology which is different from previous Islamic movements. (Ashgar, 2016). This reason is used as a tool to continue to consolidate networks in spreading their teachings and $d a^{\prime} w a h$ massively, especially in online media. When the ISIS action conquered several strategic cities in Iraq and Syria, it was used as a role model to carry out the same action in various countries, including Indonesia. Therefore, the terrorism movement through online media networks must be understood comprehensively so that stakeholders can be wiser in eradicating various terror movements that have existed so far.

Researches on terrorism and communication networks have been carried out quite a lot both abroad and domestically, but the researches on this theme seem to be divided into two types, with the first type focusing on terrorism activities in various ways and the second type focusing on terrorism communication networks. The first type of research includes studies by Zoey Reeve (2019), Steve Wood \& Simon Gardiner (2019), and Ahmet S. Yayla (2019). While terrorism research is related to communication networks, several studies in international journals include Alan Neustadti cs (2009), Arie Perliger and Ami Pedahzur (2011), and Steven T. Zech and Michael Gabbay (2016).

Publications on terrorism in Indonesia are also divided into two, which respectively discuss terrorism in various aspects and terrorism in relation to communication networks. The studies that discuss terrorism activities in various aspects include: (1) Siti Aminah (2016); (2) Sadarusalam \& Hasan (2019); (3) Hery Firmansyah (2011); (4) Muhammad Zulfikar and Aminah (2020); (5) 
Sidratahta Mukhtar (2016); (6) Andra Fahreza (2020); (7) Anwar Sadad Harahap \& Taufik Siregar (2020), and (8) Graduated Suryani (2017). Meanwhile, the publications of terrorism in relation to communication networks are found in the studies conducted by (1) Asri Sulistiawati (2017), and (2) Fajar Purwawidada (2014).

From some of these articles, it can be concluded that studies on terrorism are quite a lot carried out by researchers both abroad and domestically, some of them look at it from various aspects and the others look at it from the point of view of communication networks, yet this research has differences; of the 3 research papers on terrorism networks abroad, this research focuses on the case of the ISIS Network in Indonesia. There is one article found in foreign journals related to ISIS written by Ahmet S Yayla from Turkey, yet the study focused on reconciliation and perceptions of the terrorist threat. Then, regarding the publications in Indonesia about terrorism in relation to communication networks, from the three articles mentioned above, all of them are qualitative in nature from the results of informant interviews. There is no study using network analysis that locates the main actors who play a role in various terrorism cases in Indonesia.

The study of terrorist networks is indeed quite sensitive, not to mention the difficulty to access data that is highly protected by the authorities, in this case the State Intelligence Agency (BIN) and the National Counterterrorism Agency (BNPT), also the ability and foresight to see the spread of terrorism information contained on the internet. The author has access and competence to discuss this in terms of both study and experience since the author was a former deputy for prevention, protection, and deradicalization at the National Counter-Terrorism Agency (BNPT) in Indonesia. Therefore, this research is clearly different from previous researches, including other writings that are analytical in nature but are not supported by research results.

\section{Theoretical Framework}

Communication Network Analysis Method is a method that is now growing rapidly and is widely used in researches or studies related to communication science or other social sciences. This method has an approach which is different from other methods such as surveys and experiments. The Communication Network Analysis (CNA) method focuses on data about relationships, the context of relationships, and the position of actors in the social structure. Network research places more emphasis on actors and the relationships between actors. Emphasis on actor and relational data will provide an overview of the process of forming a communication phenomenon or event and the decisive actor in the communication structure.

In the book Communication Network Analysis by Eriyanto (2014) it is stated that there are 3 levels of analysis that can be used in communication network research, as illustrated in the following table 1:

Table 1. Level of Research Analysis and Design in Network Studies

\begin{tabular}{|c|c|c|}
\hline \multirow[b]{2}{*}{ Level of Analysis } & \multicolumn{2}{|c|}{ Study Design } \\
\hline & Complete Networks & Ego Networks \\
\hline Actor & $\begin{array}{l}\text { - Degree Centrality } \\
\text { - Closeness Centrality } \\
\text { - Betweenness Centrality } \\
\text { - Eigenvector Centrality }\end{array}$ & $\begin{array}{l}\text { - Network Closure } \\
\text { - Structural Holes } \\
\text { - The Strength }\end{array}$ \\
\hline Group & $\begin{array}{l}\text { - Component } \\
\text { - K-Core } \\
\text { - Click } \\
\text { - N-Clique } \\
\text { - K-Plexes }\end{array}$ & $\begin{array}{l}\text { - Brokerage } \\
\text { - Homophily Analysis } \\
\text { - Structural Equivalence }\end{array}$ \\
\hline System & $\begin{array}{l}\text { - Size } \\
\text { - Density } \\
\text { - Reciprocity } \\
\text { - Distance } \\
\text { - Centralization }\end{array}$ & $\begin{array}{l}\text { - Ukuran (size) } \\
\text { - Kepadatan (density) } \\
\text { - Diameter dan jarak } \\
\text { (distance) }\end{array}$ \\
\hline
\end{tabular}

Source : Communication Network Analysis (Eriyanto, 2014) 
Based on this study design, the main analytical approach used to dissect the patterns and implications of network communication in the Indonesian ISIS group is the Structural Holes theory which was introduced and developed by Ronald S Burt in Theory of Structural Holes (Burt, 1992, 1997, 1998, 2001). The structural hole is an empty space in the communication network because actors in the network do not have ties to other actors, both within and outside the communication network. These structural holes provide an opportunity for actors (tertius) who are in between these gaps to intervene or exploit. The gap structure is used to dissect the ISIS network because it focuses on the emphasis not on the communication network as a whole, but on the role of actors in exploiting the empty gaps in the communication network.

Actors in a network are generally considered to have only two roles: network breaker (gaudens) or network liaison (iungens) as can be seen in the following figure 1 :
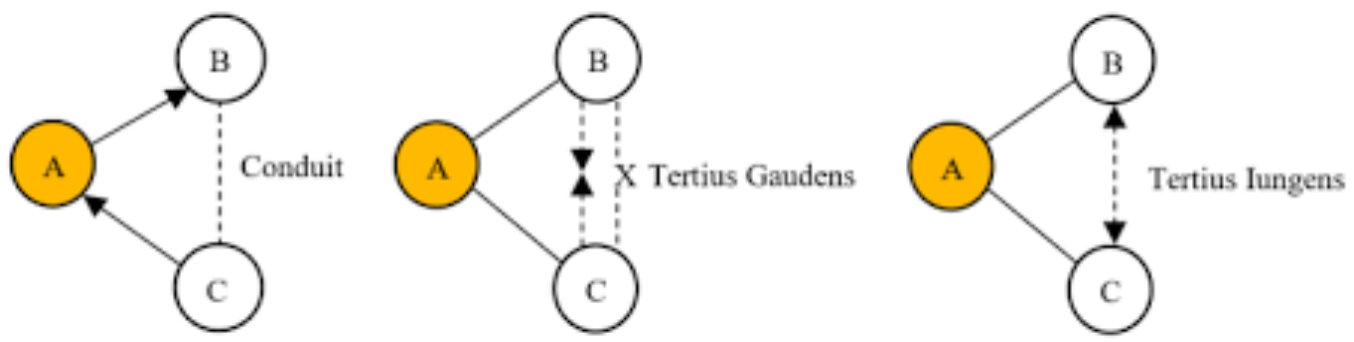

Figure 1. Role of Tertius in Communication Network Source: Berto \& Sunarwinadi, 2019:72

This research, however, succeeded in finding new facts; actors in the ISIS terrorism network were able to integrate the two roles above simultaneously. The most important actor in the ISIS network, Aman Abdurrahman, does not rigidly use either of the two strategies above. Aman is able to run the two roles at once. Aman Abdurrahman played Gaudens in the ISIS network in Jakarta and Poso, yet switched to Iungens in the ISIS Surabaya network. This shows that the approach that places "tertius gaudens" and "tertius iungens" as contradictory may indeed be relevant for other objects of study, yet in the study of terrorist group communication networks, separating the two approaches above is not always sufficient. See the following figure 2 :

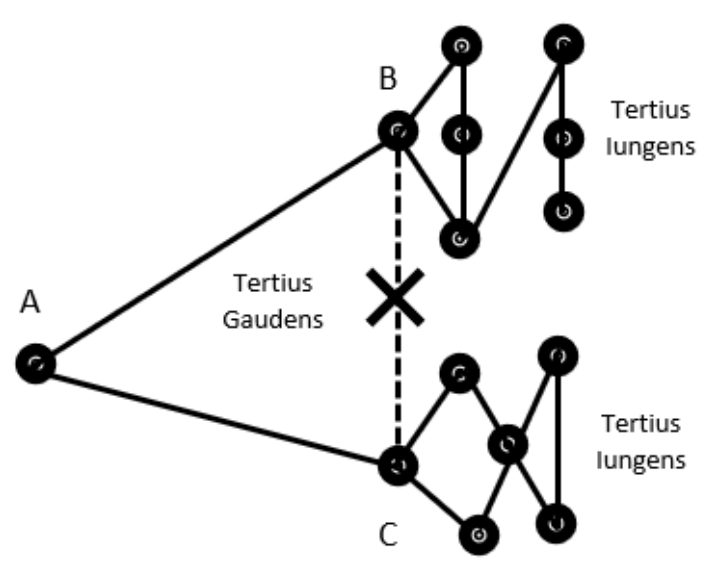

Figure 2. Integration of Tertius

The picture above shows that - in accordance with the findings in the field - the most important strategy is not applied rigidly in the field. The tertiary actor can perform two roles as iungens and gaudens simultaneously or integrate the two. Mainly because the terrorist group is often ambiguous, thus it is not enough to use only one type of approach; integration is a must.

\section{Material and Methodology}

Research on Social Network Strategy to Counter Actions of Terrorism in Indonesia: A Structural Hole Study uses a network study 
approach to determine actors and also as a communication channel for ISIS terrorist actors in Indonesia. This research is descriptive qualitative because in addition to the data obtained from the reading and analysis of the available documents, it also used a network analysis program based on statistical and isometric calculations called UCINET as one of the software that can be used to manage relational data in communication network analysis. This program was developed by Borgatti with his friends to meet the needs of analysis in the social sciences, especially in network analysis (Hsieh, 2005).

UCINET was chosen because it is relatively easy to use with a wide scope for analysis selection (Correia da Silveira Batista et al., 2018). Through UCINET, the results sought are classified based on: Density, Centrality Degree, Centrality Betweenness, Centrality Closeness, and Click as described in the design of this research study. After data entry is completed, then sociometric images and sociograms are created using NetDraw software, this software is one package with UCINET. After the sociometric images and sociograms are presented, then the data is processed using data analysis at the level of actor centrality.

\section{Result and Discussion}

Tertius Theory: A Social Network Strategy

Many studies reveal that terrorist networks carry out their actions through online media communication networks. For this reason, in understanding social network communication strategies, there are at least three strategies that need to be understood.

First, tertius gaudens. This strategy is based on conditions where someone takes advantage of the conflict, whether two or more parties carry it out. A person referred to as tertius gaudens has a role as a broker between two or more parties, where he can carry out his action as a liaison with actors for personal or group gain (Burt, 2005). In the context of terrorism networks, tertius gaudens continues to be carried out by perpetrators. When actor A and actor B are caught by state security, actor C constructs various information that actor $\mathrm{A}$ and actor B have a different relationship. There is no relationship between each other. So with that, security is difficult to trace their network.

Second, tertius iungens. This strategy is based on the fact that third parties separate actors as tertius gaudens. Still, they can also become brokers who unite or connect separate individuals in a social network. Not only that, through tertius iungens, one can facilitate the consolidation of one another to strengthen their social network. In the context of terrorism, actor $\mathrm{A}$ and actor B rarely communicate directly because if they do so, then they will be easily identified and arrested quickly. Therefore, there needs to be actor $\mathrm{C}$ as a liaison for all information from actor $\mathrm{A}$ to actor $\mathrm{B}$ to maximize his actions (Obstfeld, 2005a).

Third, a strategy that integrates tertius gaudens and tertius iungens. A person plays a single role through tertius gaudens or tertius iungens, but an actor can play multiple roles and be flexible in carrying out his actions. In the context of terrorism, terrorists flexibly carry out various actions. At certain times, they have to become tertius gaudens, and at other times they have to change their role as tertius iungens (Lingo \& O'Mahony, 2010).

In the case of ISIS terrorism in Indonesia, this third strategy is used for at least two reasons. First, group communication networks are often ambiguous, so it is impossible to apply a single strategy to exploit the network. Second, the most important actor in the ISIS communication network in Indonesia has different needs for the networks he enters. Aman Abdurrahman seemed to have a greater need for the ISIS group in Surabaya than the groups in Jakarta and Poso, that's why he became an iungens only in that group.

\section{The Urgency of National Stability in Stemming Terrorism Actions in Indonesia}

National stability must be placed above the interests of groups or individuals to safeguard the life of the nation and state. National stability has a dynamic nature and is strongly influenced by strategic environmental conditions that are constantly changing and developing (Yunus, 2016). National stability cannot be separated from stable national security conditions and situations followed by various sustainable developments. National stability is a stable state of a country which is free from various political, ideological, economic, military, etc. disturbances (Yunus, 2016), including terrorism, which is often based on political reasons.

The stronger the stability of a country, the stronger the country will be to thwart various threats of terrorism. From various studies, it is stated that someone who gets involved in acts of radicalism has specific reasons, which does not merely have implications on religious understanding. The reason that often arises is 
that someone becomes radical because of economic factors. According to Jones, the ISIS movement gives great hope that if someone joins the group. It will get a monthly salary with the details of each troop being given US\$ $50 /$ month, the salary, if the wife is brought to the battlefield, is added US\$ 50/month, and the additional salary if bringing the child is US\$ $50 /$ month. US $\$ 25 /$ month. In his research, almost the majority of Indonesian citizens who join the ISIS movement do not have permanent jobs, do not have sufficient skills, and generally have low levels of education (Jones, 2014).

Therefore, it is not surprising that since the New Order, the effort to strengthen the industrial sector has topped the list of priorities in implementing national development. It is believed to be one of the national defenses in Indonesia in facing various threats, including the threat of terrorism. Terrorism does not make this country a direct enemy. Still, if the country's position is in the middle of a crisis and national stability is disturbed, then acts of terror will threaten it (Rohmy, Suratman, \& Nihayaty, 2020).

The urgency of national stability is the primary key to continuing it to the maximum level in order to maintain national security and comfort. National development is one of the essential factors in improving people's lives to strengthen national resilience and be able to adapt to various existing changes. Therefore, synergy from various parties is needed to comprehensively understand the terrorist movement that is still operating in Indonesian territory. By understanding the network strategy, the state as the authority holder can maximize its policies to move through a soft approach so that the space for terrorism is getting narrower.

\section{Analysis of Tertius Strategy in Preventing Terrorism}

Processing information in a social network can be used as social capital, which provides many advantages. That is, in a communication network, the most important thing is information. Own capital is the integration of personal networks (Berto \& Sunarwinadi, 2017). The integration of the personnel network will strengthen the close relationship between personnel so that they can do many things for specific purposes to perpetuate the relationship (Ichsan, 2019). The integration of this social network contains the accumulation of actual and virtual resources so that it can provide its value, not only for individuals but also for groups, through mastery or ownership of networks for a long duration by establishing relationships to be recognized and known (Monge \& Contractor, 2003).

The social capital above can be used in two strategies. The first strategy is tertius gaudens (Burt, 1995). Burt developed this theory by referring to situations when a person can take advantage of a conflict between two or more people in a network (Masudi, 2015). As a third party who benefits, a tertius gaudens acts like a broker between two or more interested parties, both in working together positively and in negative conflict. Gaudens can play a role by connecting the two parties, but the relationship is not for the benefit of both parties, but on the contrary, namely for the benefit of himself and his group. That way, parties who want to connect with other parties will need the role of gaudens. Through this strategy, the bargaining value is increasing, and the capital value is also getting higher.

However, Tertius gaudens's strategy received various sharp criticisms, among others, from Obstfeld, who said that a third person not only acts as a network breaker but, on several occasions, he becomes a strong network liaison (Obstfeld, 2005). Obstfeld offered the tertius iungens strategy. Conclusively, he argues that if a third party acts as a tertius gaudens, it weakens the network. Therefore, the best strategy in understanding social networks is to connect individuals who, in reality, are not connected in a social network.

If understood in the context of terrorist networks in Indonesia, for example, the two strategies of tertius gaudens and tertius inguens have their respective emphases. They have characteristics that can be used as standards in understanding terrorism networks. It means that terrorist actors at certain times play the role of tertius gaudens to increase the bargaining power of their capital and at other times play the role of tertius inguens. It can be proven how Abu Sulaiman plays the role of tertius gaudens and has carried out various gaps in relations between other terrorist actors in various countries. As a broker, Abu Sulaiman seriously took various actions to deceive the police. Although Abu Sulaiman was arrested in 2018, the relationship between other perpetrators (besides Abu Sulaiman) is challenging to trace and difficult to find.

Not only that, actor in the bomb attack case in Thamrin Jakarta has also played this tertius gaudens strategy. Abu Sulaiman gave instructions to $\mathrm{Abu}$ Gar to break the 
communication link between terrorist actors in Indonesia and high-ranking officials in Syria. Through this strategy, Abu Sulaiman controls information to play his social capital in the network of terrorist groups in Indonesia. Even the effect of the tertius gaudens strategy is that in 2021 terrorist groups will separate from each other by carrying out their actions individually, without being tied to others, such as the bomb explosion at the Makassar Cathedral Church and the attack at the National Police Headquarters (Innews, 2021).

In addition, the tertius inguens strategy is also often carried out by terrorist groups in Indonesia in the last few years. Terrorist actors who have long disappeared and been separated, both physically and ideologically, can reconnect with one another. Abu Gar, who was still in the Nusakambangan prison, connected various other actors who were previously separated through the instructions of Abu Sulaiman. He was the one who connected Ali Hamka (as a firearms supplier) with the four executioners of the action in the field.

Abu Sulaiman also played tertius inguens with Mujahidin Indonesia Timur (MIT) group in Poso. He communicated intensively with Santoso. But Santoso used the role of tertius gaudens where he did not communicate with his subordinates. The same thing was done by Ali Kalora, Daeng Koro, and Basri. The actor who plays the tertius gaudens role is done to maintain the leading authority and is also used as a form of the sacredness of the network command line. Abu Sulaiman played the most crucial role in this gaudens to cut off communication that allowed his subordinates to communicate directly with the highest leadership of ISIS.

The role of tertius iungens was also seen in the case of the East Java-Banten terrorist network in 2020. The actors used the old network pattern, namely Jamaah Islamiyah (JI) network. The three terrorists arrested in Banten have strong links to the arrests of several suspected terrorists in East Java. Namely, someone, identified by his initials as $\mathrm{AH}$ as the attack planner by sending weapons, several executioners in the field, and Wijayanto as a distributor of funds (Arnaz, 2020). Therefore, it provides an understanding that the tertius gaudens and tertius inguens strategies still have sufficient significance in understanding the terrorism movement in Indonesia.

Not only that, but terrorists also use a strategy that combines tertius gaudens and tertius iungens. From the various examples of how the pattern of terrorist networks described above, terrorist actors seem to understand very well that carrying out several terrorist acts requires strong tactics and strategies to deceive and make it difficult for the police and the public to identify them. It can be seen how the perpetrators in Sidoarjo and Surabaya have camouflaged guidebooks. They continue to learn to blend in with the general public without knowing their true identity (Agiesta, 2018). It means that terrorist actors flexibly carry out both strategies in the field so that until now, terror acts still occur in several regions in Indonesia.

\section{Social Network Strength as Main Focus}

Actors in acts of terrorism must be understood comprehensively how to analyze social networks in the relationship between one actor and another. Focusing on the strength of the terrorist network will get the proper solution gap because it will show how the pattern of the attribution network is, such as their group network, the deepening of individuals, the link between certain institutions and the state, and so on. The relation network of relations emphasis must be seen as how the relationship works and moves, who is involved in the action, and each actor's role in the action, including what goals the relationship is trying to achieve (Eriyanto, 2014). The strength of the network is formed not only by individual relationships but also beyond geographical boundaries in the context of survival in the face of various life challenges (Runturambi, 2017).

The network power as the primary focus becomes very important to understand because, after all, an actor's attitude serves as the decision within the network. Whatever the background of a terrorist actor, when he enters a more extensive social network, he will tend to follow the pattern of relations that has been agreed upon by the network. Individuals are never understood as dependent and independent actors but interdependent with others (Vera, \& Schupp, 2006). This social network analysis not only analyzes a person's behavior, attitudes, and beliefs but also focuses more on how individual interactions construct structures that can be described accurately. The main focus in interdependent networks (especially in terrorism networks) is the actors and their position in the network and their relationship (Rowley, 1997).

If understood in the reality of acts of terrorism in Indonesia, the urgency of network strength and relations between actors is the key 
to understanding the pattern of terrorism itself. Suppose if the research only emphasizes the attribution of the actor's life background, then the research results will show that the actor is part of a specific terrorist group, such as the long-lost Jamaah Islamiyah (JI) network group. But if the research focus is understood from the strength of the network of relations between actors, then each actor will be understood as a small part of a network that may be larger than the group he is currently following. It is like how terrorism groups in Indonesia have revived JI's relations with neo-JI in carrying out their current terror acts.

Actors in research that focus on network strength cannot be classified as members of a particular group. Still, in reality, terror actors always establish communication and relationships with other actors. By understanding social networks, this relationship can be interpreted as a relationship without boundaries. Primarily if it is understood in today's digital era, the power of the network is getting easier to move, like 'moving both palms' (Liao, \& Phan, 2016). It's not surprising that Castell (2009) mentioned that the network community would build a network without being limited and challenging to censor easily. Network communities can mobilize joint forces to fight for all their interests. Each individual can form a social network that allows individuals to coordinate, open up interactive discussion spaces, and quickly mobilize collective actions (Holmes, 2005).

\section{Integration Strategy as a Solution of Deradicalization}

The different roles of terrorist actors in the field prove that the tertius strategy is carried out flexibly, not rigidly. That is, tertius gaudens and tertius iungens are not a single choice. Actors can choose to act as gaudens or iungens, depending on the situation and needs on the ground (Lingo \& O'Mahony, 2010). Therefore, the tertius strategy has opened a complete understanding for network communication observers, especially the government as a stakeholder and national policy. The purpose of understanding the tertius strategy is to identify potential problems that exist and determine appropriate interventions in overcoming all problems, especially tackling acts of terrorism. For this reason, as a reinforcement of social control due to the distribution of information through online media, it is necessary to have a tertius guide that can be used to form and maintain existing gaps to be entered and controlled for the common good (Berto \& Sunarwinadi, 2017).

The ultimate strategy in understanding terrorism networks is one of the essential solutions in deradicalization. Under any circumstances, the tertius role has many advantages (Monge \& Contractor, 2003). Here, at least tertius has three advantages, namely access, timing, and referrals. First, access. Through access, Tertius can control various types of information, both through the 'real world' and 'virtual world,' to determine from where the information is given. Second, timing. Through the right time, tertius can build relationships with the parties concerned to intervene to receive various information from tertius in total. Third, referrals. When tertius is used as a strong control force, he will become a reference for the parties connected to the network. From this point, tertius has high bargaining power because he has earned the trust of various parties so that terrorism can be prevented more efficiently and effectively because of the various kinds of exploitation and information channels he gets.

Tertius can be used as an essential strategy by the government in preventing terrorism in Indonesia. The government positions itself as the integration holder to exploit incoming information. In the ultimate strategy, the government can perform two functions. First, the government can carry out the tertius gaudens function in case of competition between two parties for the same information. Thus, through the tertius gaudens, the government has total control as a controller to determines who will be given information. Second, the government can also play the role of tertius inguens if the two parties are in a position separated by conflict and so on. Through the tertius inguens, the government acts as a mediator that connects the disputing parties to find the right solution to the conflict.

Considering that terrorism is an extraordinary crime, transnational crime, and crime against humanity, various parties must have a synergy strategy. First, the government needs to continue synergizing with former terrorist members in carrying out their role as tertius gaudens to terrorist actors, both inside and outside prisons scattered in various regions. Through the tertius gaudens, the actors will find it difficult to get communication in their network to cut off the line of command. Eventually, the terrorist network will be weakened to develop their movement. Second, the government synergizes with various 
ministries and institutions involving community leaders, religion, academics, educators, youth, and peace activists. The government can act as a tertius iungens who reconnect communications between terrorist actors to moderate-nationalist groups. Through the tertius iungens strategy, the government can intervene in actors to leave the network.

Deradicalization through the tertius strategy requires cross-institutional roles and contributions, both through the contribution of physical and non-physical support. The Ministry of Religion can play an essential role in fostering and enlightening the lecturers regarding contemporary-modern, accommodating, acculturative, and conciliatory national insights. It is essential to do to ward off radical religious understanding in society at large. Although the lecturers have played an active role in enlightening the community so far, a strong synergy between institutions is needed to move together in carrying out massive deradicalization.

The approach to empower the people's economy also needs to be intensified through the Ministry of Economy or Cooperatives and Small and Medium Enterprises. To that end, the ministry can take on a role by providing interest-free business capital loans to exterrorists, terrorist families, and those vulnerable to becoming terrorists. The Ministry of Communication and Informatics also needs to play an essential role in constructing information related to correct understanding of religion and state. This ministry also needs to create content in all media on fostering the importance of unity among citizens, regardless of race, religion, ethnicity, and class. By doing so, positive content can create an atmosphere where all Indonesian citizens feel safe, comfortable, and peaceful. Because differences are a necessity, unity is an obligation for all Indonesian citizens.

\section{Conclusion}

The different roles played by the tertius actor in these three ISIS communication networks show that gaudens and iungens are not two opposing entities. Both can be used simultaneously. The study of structural hole theory, which is generally seen as an approach that places the Iungens and Gaudens strategies in opposite poles, has actually anticipated the emergence of new innovations related to communication strategies in networks, including the possibility of the emergence of Iungens and Gaudens synergistic strategies.
This can be seen from the emergence of the concept of nexus work, namely a communication strategy that relies on the ability of intermediary actors to integrate the two most important strategies with a dialectical approach when facing the dynamics of ambiguous situations in the communication process.

When the communication conditions and situations are uncertain (ambiguous), using one type of approach will certainly not be of much help. Therefore, instead of choosing between iungens or gaudens, intermediary actors can use both at the same time, of course, taking into account the uncertainty; and it is a strategy integration, along with a description of the form and work pattern of intermediary actors when integrating two strategies, iungens and gaudens.

By applying the theory of structural holes, terrorism prevention can be focused on the holes or gaps that exist in the structure of the terrorist group's communication network. By exploiting these loopholes, network members can be influenced and return to the Republic of Indonesia, so that there is no need to become terrorists anymore.

\section{References}

Agiesta, F. S. (2018). 4 Penemuan Mengejutkan Peninggalan Teroris Setelah Digeledah Polisi. merdeka.com. Repéré à https://www.merdeka.com/peristiwa/4penemuan-mengejutkan-peninggalanteroris-setelah-digeledah-polisi.html

Aljunied, S. M. A. (2011). Religious Freedom in Malaysia's 'Islamic State': Comparisons with the Islamic State of Medina. Journal of Muslim Minority Affairs, 31(1), 112-123.

Aminah, S. (2016). Peran pemerintah menanggulangi radikalisme dan terorisme di Indonesia. Inovasi Pembangunan: Jurnal Kelitbangan, 4(01), 83-101.

Arnaz, F. (2020). Jaringan Teroris JatimBanten Gunakan Strategi JI. Berita Satu. Repéré https://www.beritasatu.com/nasional/626 555/jaringan-teroris-jatimbantengunakan-strategi-ji

Ashgar, A. (2016). Gerakan Terorisme tahun 2015: Pola Serangan, Jumlah Korban, dan Wajah Baru Global Jihad. Jurnal Keamanan Nasional, 2(1). 
Bakti, A. S. (2014). Merintis Jalan Mencegah Terorisme (Sebuah Bunga Rampai). Jakarta: Semarak Lautan Warna.

Bakti, A. S. (2016). Perang Semesta Berbasis Kearifan Lokal Melawan Radikalisasi dan Terorisme. Jakarta: Daulat Press.

Berto, AR. \& Sunarwinadi, I. (2017). Are the Structural Holes a Form of Social? A Theoretical Debate. Dans International Conference on Administrative Science, Policy and Governance Studies (ICASPGS). Depok: Atlantis Press.

Berto, A. R., \& Sunarwinadi, I. R. S. (2019). The Holes in Structural Holes Theory (A Literature Review). Proceedings of the Social and Humaniora Research Symposium (SoRes 2018). https://dx.doi.org/10.2991/sores18.2019 .16

Burt, R.S. (1995). Structural Holes: The Social Structure of Competition. Massachusetts: Harvard University Press.

Burt, R. S. (2005). Brokerage \& Closure: An Introduction to Social Capital. New York: Oxford University Press.

Castell, M. (2009). Communication Power. New York: Oxford University Press.

da Silveira Batista, H. M. C., y Rodriguez, M. V. R., Cardoso, K. A. W., Costa, H. G., \& Dias, A. C. (2018). The social network analysis and its contribution to the mapping of scientific production in postgraduate programs. Brazilian Journal of Operations \& Production Management, 15(2), 330-342.

Eriyanto. (2014). Analisis Jaringan Komunikasi: Strategi Baru dalam Penelitian Ilmu Komunikasi dan Ilmu Sosial Lainnya. Jakarta: Kencana.

Fahreza, A. (2020). Pencegahan Terorisme Berbasis Masyarakat Dengan Pembentukan Forum Koordinasi Pencegahan Terorisme Di Tiga Provinsi. Jurnal Sosiologi Nusantara, 6(1), 13-22.

Farisa, F. C. (2021). 552 Aksi Teror Terjadi Sejak Tahun 2000, Terbanyak Ada di Era $S B Y$. Kompas. Repéré à https://nasional.kompas.com/

Firmansyah, H. (2011). Upaya Penanggulangan Tindak Pidana Terorisme di Indonesia. Mimbar Hukum, 23(2). https://doi.org/https://doi.org/10.22146/j mh.16193

Fitriani, A. S., Putri, P., Sari, N., \& Adriana, R. (2018). The Current State of Terrorism in Indonesia: Vulnerable Groups, Networks, and Responses. Dans Center for Strategic and International Studies. Jakarta.

Harahap, A. S., \& Siregar, T. (2020). Model Pencegahan Tindak Pidana Terorisme Berbasis Adat Dalihan $\mathrm{Na}$ Tolu di Tapanuli Selatan. Pandecta Research Law Journal, 15(2), 295-310. https://doi.org/https://doi.org/10.15294/p andecta.v15i2.24678

Hikam, M. A. S. (2016). Deradikalisasi: Peran Masyarakat Sipil Indonesia Membendung Radikalisme. Jakarta: Kompas.

Holmes, D. (2005). Communication Theory: Media, Technology, and Society. London: Sage Publication Ltd.

Hsieh, H. F., \& Shannon, S. E. (2005). Three approaches to qualitative content analysis. Qualitative health research, 15(9), 1277-1288.

Ichsan, A. S. (2019). Konstruksi Pendidikan Relasi Kiai dan Santri di Pondok Pesantren Lintang Songo Piyungan Yogyakarta. Jurnal Darussalam: Jurnal Pendidikan, Komunikasi dan Pemikiran Hukum Islam, 11(1). https://doi.org/https://doi.org/10.30739/d arussalam.v11i1.458

Innews. (2021). Setara Institute Ungkap Strategi Baru Kelompok Teroris. Innews. Repéré à https://innews.co.id/setarainstitute-ungkap-strategi-barukelompok-teroris/

Ivankova, N. V., Creswell, J. W., \& Stick, S. L. (2006). Using mixed-methods sequential explanatory design: From theory to practice. Field methods, 18(1), 3-20.

Jones, S. (2014). The Evolution of ISIS in Indonesia. IPAC Report, (13), 18.

Karlsen, R. (2015). Followers Are Opinion Leaders: The Role of People in the Flow of Political Communication on and Beyond Social Networking Sites. European Journal of Communication, 30(3),

$1-18$. 
https://doi.org/10.1177/02673231155773 05

Liao, Y.-C., \& Phan, P. H. (2016). Internal Capabilities, External Structural Holes Network Positions, and Knowledge Creation. The Journal of Technology Transfer.

https://doi.org/https://doi.org/10.1007/s1 0961-015-9415-x

Lingo, EL., \& O'Mahony, S. (2010). Nexus Work: Brokerage on Creative Projects. Administrative Science Quarterly, 55(1). https://doi.org/https://doi.org/10.2189/as qu.2010.55.1.47

Masudi. (2015). Akar-akar Teori Konflik: Dialektika Konflik; Core Perubahan Sosial dalam Pandangan Karl Marx dan George Simmel. Fikrah, Jurnal Ilmu Aqidah dan Studi Keagamaan, 3(1).

Monge, PR. \& Contractor, N. (2003). Theories of Communication Networks. New York: Oxford University Press.

Mukhtar, S. (2016). Strategi Pemerintah Indonesia Menghadapi Terorisme dalam Era Demokratisasi. Reformasi: Jurnal Ilmiah Ilmu Sosial dan Ilmu Politik, 6(2). https://doi.org/https://doi.org/10.33366/r fr.v6i2.691

Obstfeld, D. (2005). Social Networks, the Tertius iungens Orientation, and Involvement in Innovation. Administrative Science Quarterly, 1(1). https://doi.org/10.2189/asqu.2005.50.1.1 00

Perliger, A., \& Pedahzur, A. (2011). Social network analysis in the study of terrorism and political violence. PS: Political Science \& Politics, 44(1), 45-50.

Purwawidada, F. (2014). Jaringan Teroris Solo Dan Implikasinya Terhadap Keamanan Wilayah Serta Strategi Penanggulangannya (Studi Di Wilayah Solo, Jawa Tengah). Jurnal Ketahanan Nasional, 20(1), 1-22.

Reeve, Z. (2019). Terrorism as parochial altruism: Experimental evidence. Terrorism and Political Violence, 1-24.

Rohmy, A. M., Suratman, T., \& Nihayaty, A. I. (2020). Peranan Tentara Nasional Indonesia dalam Penindasan Terorisme Berbasis Agama. At-Turas: Jurnal Studi Keislaman, $7(1)$, 101. https://doi.org/http://doi.org/10.33650/at -turas.v7i1.1012

Rowley, T. J. (1997). Moving Beyond Dyadic Ties: A Network Theory of Stakeholder Influences. Academy of Management Review, 22(4).

Runturambi, A. J. S. (2017). Analisa Jaringan Sosial dalam Menelusuri Budaya Menyimpang di Lembaga Pemasyarakatan. Deviance: Jurnal Kriminologi, 1(1), 5.

Runturambi, A. J. S. (2017). Analisa Jaringan Sosial dalam Menelusuri Budaya Menyimpang di Lembaga Pemasyarakatan. Deviance: Jurnal Kriminologi, 1(1), 5 .

Sadarusalam, B. W. A., \& Hasan, K. (2019). Kontra Propaganda Badan Nasional Penanggulangan Terorisme dalam Menanggulangi Perkembangan Radikalisme di Indonesia. The Indonesian Journal of Politics and Policy, 1(1).

Sugiyono. (2016). Metode Penelitian dan Pengembangan (Research and Development $/ R \& D)$. Bandung: Alfabeta.

Sulistiawati, A. (2018). Analisis Jaringan Komunikasi Tingkat Kelompok dalam Gapoktan. Jurnal Sains Komunikasi dan Pengembangan Masyarakat 2(2), 155168.

Suryani, T. (2017). Terorisme dan Deradikalisasi: Pengantar Memahami Fundamentalisme Islam dan Strategi Pencegahan Aksi Terorisme. Jurnal Keamanan Nasional, 3(2).

Vera, E. R., \& Schupp, T. (2006). Network Analysis in Comparative Social Sciences. Comparative Education, 42(3).

Wood, S., \& Gardiner, S. (2019). Policing UK airports and schedule 7 of the terrorism act 2000: The young passengers' perception of security measures. Terrorism and Political Violence, 1-22.

Yayla, A. S. (2019). Turkish ISIS and AQ foreign fighters: Reconciling the numbers and perception of the terrorism threat. Studies in Conflict \& Terrorism, 1-23.

Yunus, M. (2016). Kajian Konsep Stabilitas Nasional terhadap Pengaruh Lingkungan Strategis. Lemhannas RI. Repéré à http://www.lemhannas.go.id 
Zech, S. T., \& Gabbay, M. (2016). Social network analysis in the study of terrorism and insurgency: From organization to politics. International Studies Review, 18(2), 214-243.
Zulfikar, M., \& A. (2020). Peran Badan Nasional Penanggulangan Terorisme dalam Pemberantasan Terorisme di Indonesia. Jurnal Pembangunan Hukum Indonesia, 2(1). https://doi.org/https://doi.org/10.14710/j phi.v2i1.129-144 